\title{
INSIG2 rs7566605 single nucleotide variant and global DNA methylation index levels are associated with weight loss in a personalized weight reduction program
}

\author{
FRANCESCA PIRINI $^{1}$, SEBASTIAN RODRIGUEZ-TORRES ${ }^{2}$, BOLA GRACE AYANDIBU ${ }^{2}$, \\ MARÍA ORERA-CLEMENTE ${ }^{3}$, ALBERTO GONZALEZ-DE LA VEGA ${ }^{4}$, FAHCINA LAWSON $^{2}$, \\ ROLAND J. THORPE JR ${ }^{5}$, DAVID SIDRANSKY ${ }^{2}$ and RAFAEL GUERRERO-PRESTON ${ }^{2,6}$
}

\begin{abstract}
${ }^{1}$ Biosciences Laboratory, Istituto Scientifico Romagnolo per lo Studio e la Cura dei Tumori (IRST) IRCCS, I-47014 Meldola, Italy; ${ }^{2}$ Department of Otolaryngology, School of Medicine, Johns Hopkins University, Baltimore, MD 21231, USA; ${ }^{3}$ Genetic Laboratory, University General Hospital Gregorio Marañón, 28007 Madrid; ${ }^{4}$ Molecular Genetics and Clinical Genetics Department, CGC Genetics, 28016 Madrid, Spain; ${ }^{5}$ Johns Hopkins University Centre for Health

Disparities Solutions, Johns Hopkins Bloomberg School of Public Health, Baltimore, MD 21205; ${ }^{6}$ Department of

Obstetrics and Gynecology, School of Medicine, University of Puerto Rico, San Juan, PR 00936-5067, USA
\end{abstract}

Received July 26, 2017; Accepted August 17, 2017

DOI: $10.3892 / \mathrm{mmr} .2017 .8039$

\begin{abstract}
Single nucleotide polymorphisms associated with lipid metabolism and energy balance are implicated in the weight loss response caused by nutritional interventions. Diet-induced weight loss is also associated with differential global DNA methylation. DNA methylation has been proposed as a predictive biomarker for weight loss response. Personalized biomarkers for successful weight loss may inform clinical decisions when deciding between behavioral and surgical weight loss interventions. The aim of the present study was to investigate the association between global DNA methylation, genetic variants associated with energy balance and lipid metabolism, and weight loss following a non-surgical weight loss regimen. The present study included 105 obese participants that were enrolled in a personalized weight loss program based on their allelic composition of the following five energy balance and lipid metabolism-associated loci: Near insulin-induced gene 2 (INSIG2); melanocortin 4 receptor; adrenoceptor $\beta 2$; apolipoprotein A5; and G-protein subunit $\beta 3$. The present study investigated
\end{abstract}

Correspondence to: Dr Rafael Guerrero-Preston, Department of Otolaryngology, School of Medicine, Johns Hopkins University, 1550 Orleans Street, Cancer Research Building II, Room 5M06, Baltimore, MD 21231, USA

E-mail: rafael.guerrero@upr.edu

Key words: near insulin-induced gene 2, melanocortin 4 receptor, adrenoceptor $\beta 2$, apolipoprotein A5, G-protein subunit $\beta 3$, global DNA methylation index, energy balance, single nucleotide variant, obesity, lipid metabolism, personalized weight reduction program the association between a global DNA methylation index (GDMI), the allelic composition of the five energy balance and lipid metabolism-associated loci, and weight loss during a 12 month program, after controlling for age, sex and body mass index (BMI). The results demonstrated a significant association between the GDMI and near INSIG2 locus, after adjusting for BMI and weight loss, and significant trends were observed when stratifying by gender. In conclusion, a combination of genetic and epigenetic biomarkers may be used to design personalized weight loss interventions, enabling adherence and ensuring improved outcomes for obesity treatment programs. Precision weight loss programs designed based on molecular information may enable the creation of personalized interventions for patients, that use genomic biomarkers for treatment design and for treatment adherence monitoring, thus improving response to treatment.

\section{Introduction}

Obesity is a major public health concern, and contributes to morbidity and mortality rates via associations with chronic diseases $(1,2)$, including type 2 diabetes mellitus, cardiovascular diseases, osteoarthritis and certain types of cancer (3). Although weight loss through dietary regimes and exercise is commonly prescribed, there is minimal insight into the molecular basis of weight loss, particularly concerning disparities in the extent of weight loss among individuals $(4,5)$. The observed differences in weight loss among individuals is an important issue for clinicians and patients, and these differences are predominantly observed between males and females undergoing the same treatment courses (6).

The current understanding of the etiology of obesity and weight loss involves environmental, genetic and epigenetic factors $(4,7,8)$. External factors in the pathogenesis of obesity include diet, physical exercise and stress. Previous studies 
indicate that single nucleotide polymorphisms (SNPs) are also important determinants of weight loss $(8,9)$. It is accepted that genetic factors partially determine individual susceptibility to weight gain and obesity, however, the established genetic variants only partially explain the variation observed. As a result, interest in understanding the potential role of epigenetics as a mediator of gene-environment interactions in obesity development has increased (10). Previous studies have investigated gene-environment interactions associated with the development of obesity (4,11-13). The initial studies focused on the associations between obesity and global DNA methylation (14-16). Global DNA methylation refers to the overall level of methylcytosine in the genome as a percentage of total cytosine, while gene-specific methylation refers to the methylation status of a specific site. While numerous studies have reported a complex association between global DNA methylation and body mass index (BMI), there is no consistent evidence for an association between global DNA methylation and obesity, which may be due to the lack of a gold standard method of measuring global DNA methylation (14,17-22). Genome-wide arrays have demonstrated a concurrent loss of methylation in the non-coding areas of the genome and gain of methylation in $\mathrm{CpG}$ islands located on promoter regions of obese patients with a high BMI, compared with patients with a low BMI. The studies also identified multiple obesity-associated differentially methylated sites, primarily in blood cells (23-26).

Cytosine methylation in SNPs (allele-specific methylation) has previously been successfully investigated in weight loss (9). Accumulating evidence indicates that the tendency towards adult obesity has early developmental origins, which are associated with a 'nutritional memory response' that can take form in epigenetic modifications during a lifetime. Associations between methylation marks at birth and later life obesity were reported (14,27-36). However, to the best of our knowledge, the potential genetic and epigenetic interactions associated with weight loss have not previously been investigated (37-41).

The present study aimed to investigate the genetic and epigenetic alterations associated with weight loss in a population of obese patients participating in a personalized weight loss program, which was designed based on genetic information. Personalized weight loss diets and lifestyle modification plans were provided to study participants according to the combined SNP profiles of five genes associated with energy balance and lipid metabolism. The present study determined the association between a global DNA methylation index (GDMI) and the allelic composition of near insulin-induced gene 2 (INSIG2), melanocortin 4 receptor $(M C 4 R)$, adrenoceptor $\beta 2(A D R B 2)$, apolipoprotein A5 (APOA5) and G-protein subunit $\beta 3$ (GNB3) in 105 obese or overweight patients that participated in a 12 month program.

\section{Materials and methods}

Study participants. The patients were referred to the Clinical Genetics laboratory of CGC (Madrid Spain) between January 2009 and June 2010, by either an endocrinologist or a dietitian in order to establish a healthy lifestyle intervention based on the risk of obesity inherent to each polymorphism investigated. Upon arrival at the clinic, the patients answered a questionnaire regarding previous health issues, including surgery, pathologies, diabetes and cardiovascular disease, and their height and present weight was recorded. The Institutional Review Boards of the Johns Hopkins University School of Medicine (Baltimore, MD, USA) approved the protocol for the present study. All participants signed an informed consent form where it was specifically stated that the samples may be used for anonymized research studies and for publications.

Personalized weight reduction program. The patients participated in a personalized weight reduction program guided by their genotypic profile, which included SNP-associated dietary recommendations, for 12 months. The BMI in $\mathrm{kg} / \mathrm{m}^{2}$ was calculated for each participant prior to and after completion of the personalized weight reduction program. Adult obesity was defined as a BMI of $\geq 30 \mathrm{~kg} / \mathrm{m}^{2}$, and patients were classified as overweight if they had a BMI between 25 and $29.9 \mathrm{~kg} / \mathrm{m}^{2}$. The participants underwent a personalized weight reduction program based on their genotypic profile. This method utilized SNP data to develop dietary recommendations. Participants also provided data regarding age at maximum weight recorded, previous dietary interventions and maximum weight loss. Additionally, women provided details regarding age at menarche and pregnancy history, in addition to height and weight prior to and following menarche and pregnancy. The polymorphisms were investigated in our laboratory and the results were disclosed in a post-test genetic counseling session.

The dietary and lifestyle interventions were subsequently tailored to the genotype of each patient by their endocrinologist/dietitian, following the general recommendations provided by the laboratory, as described in Table I. Genetic information and lifestyle modification recommendations were provided during the initial counseling session and adherence was determined at follow-up by the referring endocrinologist/dietitian. Patients were provided with a personalized weight reduction program, with primary and preferential lifestyle interventions, together with supplemental activities for each SNP of the five loci in the panel. The descriptions of sequence variants presented in Table I follow the Human Genome Variation Society 2016 recommended format (42). The five loci selected for this intervention are collectively associated with energy balance and lipid metabolism in $\geq 1$ of the following metabolic pathways or conditions: Development of obesity, high BMI, hyperphagia, hyperinsulinemia, lipolysis control, lipid metabolism homeostasis and exercise-induced weight loss (43-65).

Information on the well-established associations between each SNP and the risk of obesity was also provided to each patient. Each patient received up to three personalized dietary/lifestyle recommendations, based on their individual genotypic mosaic, which included a combination of physical activity and diets low in calories, carbohydrates and/or lipids.

DNA isolation. DNA was extracted from peripheral blood mononuclear cell (PBMC) samples obtained from all participants, and all samples were kept at $-80^{\circ} \mathrm{C}$ until analysis. Blood was collected in $4 \mathrm{ml}$ vacutainer tubes containing EDTA 
Table I. Recommended diet and lifestyle interventions for overweight patients with specific variants of five loci associated with energy balance and lipid metabolism.

\begin{tabular}{|c|c|c|c|c|c|c|c|}
\hline \multirow[b]{2}{*}{$\begin{array}{l}\text { Gene }(\mathrm{SNP}) \\
\text { and variants }\end{array}$} & \multirow[b]{2}{*}{$\begin{array}{l}\text { Physical } \\
\text { activity }\end{array}$} & \multicolumn{3}{|c|}{ Diet } & \multirow[b]{2}{*}{ HGVS name } & \multirow[b]{2}{*}{$\mathrm{MAF} /$ minor allele count } & \multirow[b]{2}{*}{ Health effects } \\
\hline & & $\begin{array}{l}\text { Low } \\
\text { calorie }\end{array}$ & $\begin{array}{l}\text { Low } \\
\text { carbohydrate }\end{array}$ & $\begin{array}{l}\text { Low } \\
\text { lipid }\end{array}$ & & & \\
\hline $\begin{array}{l}\text { Near INSIG2 } \\
(\text { rs7566605) }\end{array}$ & & & & & $\begin{array}{l}\text { NC_000002.12: } \\
\text { g.118078449C>G }\end{array}$ & $\begin{array}{l}\mathrm{C}=0.2859 / 1432 \\
(1000 \text { Genomes project) } \\
\mathrm{C}=0.2798 / 8146 \text { (TOPMed) }\end{array}$ & $\begin{array}{l}\text { Obesity, dyslipidemia, } \\
\text { control of lipid } \\
\text { synthesis }\end{array}$ \\
\hline GG and GC & $\mathrm{NI}$ & NI & NI & $\mathrm{NI}$ & & & \\
\hline $\mathrm{CC}$ & $\mathrm{b}$ & $\mathrm{a}$ & NI & d & & & \\
\hline $\begin{array}{l}M C 4 R \\
(\mathrm{rs} 17782313)\end{array}$ & & & & & $\begin{array}{l}\text { NC_000018.10: } \\
\text { g.60186834T>C }\end{array}$ & $\begin{array}{l}A=0.2400 / 1202 \\
(1000 \text { Genomes project }) \\
A=0.2503 / 7289 \text { (TOPMed) }\end{array}$ & $\begin{array}{l}\text { Obesity, obesity-related } \\
\text { quantitative traits }\end{array}$ \\
\hline $\mathrm{TT}$ & NI & NI & NI & NI & & & \\
\hline $\mathrm{CT}$ & $\mathrm{d}$ & $\mathrm{c}$ & NI & $\mathrm{d}$ & & & \\
\hline $\mathrm{CC}$ & c & $\mathrm{b}$ & NI & $\mathrm{b}$ & & & \\
\hline $\begin{array}{l}A D R B 2 \\
\text { (rs 1042714) }\end{array}$ & & & & & $\begin{array}{l}\text { NC_000005.10: } \\
\text { g.148826910G }>C\end{array}$ & $\begin{array}{l}\mathrm{G}=0.3166 / 38431(\mathrm{ExAC}) \\
\mathrm{G}=0.2043 / 1023 \\
(1000 \text { Genomes project) } \\
\mathrm{G}=0.3400 / 4422(\mathrm{GO}-\mathrm{ESP}) \\
\mathrm{G}=0.2960 / 8620 \text { (TOPMed) }\end{array}$ & $\begin{array}{l}\text { Obesity, susceptibility } \\
\text { to metabolic syndrome }\end{array}$ \\
\hline $\mathrm{CC}$ & NI & NI & NI & NI & & & \\
\hline $\mathrm{CG}$ & d & d & $\mathrm{b}$ & NI & & & \\
\hline GG & NI & d & $\mathrm{b}$ & $\mathrm{d}$ & & & \\
\hline $\begin{array}{l}\text { APOA5 } \\
(\text { rs662799) }\end{array}$ & & & & & $\begin{array}{l}\text { NC_000011.10: } \\
\text { g.116792991G>A }\end{array}$ & $\begin{array}{l}G=0.1629 / 816 \\
(1000 \text { Genomes project) } \\
G=0.1043 / 3038 \text { (TOPMed) }\end{array}$ & $\begin{array}{l}\text { Obesity, triglyceride } \\
\text { metabolism, } \\
\text { cardiovascular disease }\end{array}$ \\
\hline AA & NI & NI & NI & NI & & & \\
\hline $\mathrm{AG}$ and $\mathrm{GG}$ & $\mathrm{b}$ & d & NI & a & & & \\
\hline $\begin{array}{l}\text { GNB3 } \\
\text { (rs5443) }\end{array}$ & & & & & $\begin{array}{l}\text { NC_000012.12: } \\
\text { g.6845711C }>\mathrm{T}\end{array}$ & $\begin{array}{l}\mathrm{T}=0.3598 / 43631(\text { ExAC }) \\
\mathrm{T}=0.4498 / 5850(\text { GO-ESP })\end{array}$ & $\begin{array}{l}\text { Plasma triglyceride } \\
\text { regulation, essential } \\
\text { hypertension }\end{array}$ \\
\hline $\mathrm{CC}$ & d & d & NI & d & & & \\
\hline $\mathrm{CT}$ & NI & NI & NI & $\mathrm{NI}$ & & & \\
\hline TT & a & $\mathrm{d}$ & NI & $\mathrm{d}$ & & & \\
\hline
\end{tabular}

The description of sequence variants follows the HGVS 2016 recommended format. All are genomic sequences. $<$ REFERENCE_SEQUENCE_ ID $>:<$ SEQUENCE_TYPE $>$. $<$ POSITION $><$ CHANGE $>$. MAF refers to the frequency at which the second most common allele occurs in a given population. The MAF/minimum allele count numbers for a specific SNP represent the frequency of the allele in a sequencing project database (i.e., 1000 Genomes) and the number of times this SNP was observed in that population. SNP information was accessed from dbSNP (https://www.ncbi.nlm.nih.gov/SNP) on July 3, 2017. SNP, single nucleotide polymorphism; HGVS, Human Genome Variation Society; MAF, minor allele frequency; INSIG2, insulin-induced gene 2; NI, no intervention; NHLBI, National Heart, Lung and Blood Institute; TOPMed, NHLBI Trans-Omics for Precision Medicine project; MC4R, melanocortin 4 receptor; ADRB2, adrenoceptor $\beta 2$; ExAC, Exome Aggregation Consortium; GO-ESP, NHLBI GO Exome Sequencing Project; APOA5, apolipoprotein A5; GNB3, G-protein subunit $\beta 3$. ${ }^{\mathrm{a} R e c o m m e n d e d}$ as primary intervention; ${ }^{b}$ recommended as preferential intervention; ${ }^{c}$ recommended as primary supplemental activity; ${ }^{\mathrm{d}}$ recommended as supplemental activity.

(BD Biosciences, Franklin Lakes, NJ, USA). Whole blood was centrifuged at $300 \mathrm{x} g$ for $10 \mathrm{~min}$ and the leukocyte layer was separated, adding the same volume of PBS (0.01 M PO4, $0.15 \mathrm{M} \mathrm{NaCl}, \mathrm{pH}$ 7.2). The resulting mixture was carefully placed on Ficoll-Paque (17-1440-02), followed by centrifugation at $700 \mathrm{x}$ g for $30 \mathrm{~min}$. The corresponding leukocyte portion was separated in another tube and centrifuged at
$300 \mathrm{x} g$ for $10 \mathrm{~min}$. The supernatant was discarded and the material precipitated was washed with $1 \mathrm{ml}$ PBS (0.01 M PO4, $0.15 \mathrm{M} \mathrm{NaCl}, \mathrm{pH} 7.2)$ by centrifugation at $300 \mathrm{x} \mathrm{g}$ for $10 \mathrm{~min}$ and resuspended in $200 \mu \mathrm{l} \mathrm{NET} 100(5 \mathrm{M} \mathrm{NaCl}, 1 \mathrm{M}$ Tris- $\mathrm{HCl}$, $0.5 \mathrm{M}$ EDTA, $\mathrm{pH} 8.0$ ) to be stored at $-20^{\circ} \mathrm{C}$. The concentration of cells was determined by manual cell counting using a Neubauer chamber and divided into three equal aliquots. 
PBMC DNA samples were sent to the Head and Neck Cancer Research Laboratory of Johns Hopkins School of Medicine where they were digested with $50 \mu \mathrm{g} / \mathrm{ml}$ proteinase $\mathrm{K}$ in the presence of $1 \%$ sodium dodecyl sulfate at $48^{\circ} \mathrm{C}$ for 3 days, which was followed by phenol/chloroform extraction and ethanol precipitation, and finally dissolved in $30 \mu \mathrm{l}$ LoTE (2.5 mmol/1 EDTA and $10 \mathrm{mmol} / \mathrm{l}$ Tris- $\mathrm{HCl})$, as previously described (66).

Global DNA methylation assays. In total, sufficient DNA levels were obtained from 95 samples for the global DNA methylation analysis. The global DNA methylation levels were determined with an ELISA-based commercial kit (Imprint Methylated DNA Quantification kit; cat no. MDQ1; Sigma-Aldrich, St Louis, MO, USA), according to the manufacturer's protocol. The MDQ1 kit is a high-throughput molecular biology kit, which employs a 96-well plate format to provide accurate differential global DNA methylation absorbance readings with as little as $50 \mathrm{ng}$ genomic DNA. In the present study, $2 \mu \mathrm{l}$ DNA at a concentration of $100 \mathrm{ng} / \mu \mathrm{l}$ was diluted with $28 \mu \mathrm{l}$ lysis and binding buffers, and incubated at $37^{\circ} \mathrm{C}$ for $60 \mathrm{~min}$. The samples were incubated with capture and detection antibodies and absorbance was read at $450 \mathrm{~nm}$. Quantification of global DNA methylation was performed by calculating the amount of methylated cytosine (5-methylcytosine) in the sample relative to the global cytidine (5-methylcytosine + deoxycytosine) in a positive control that had been previously methylated. All samples were analyzed in duplicate.

SNP analysis. DNA was genotyped using made-to-order TaqMan SNP Genotyping Assays with the following cat no. 4351379 and assay IDs: C_29404113_20 (near INSIG2-rs7566605); C_32667060_10 (MC4R-rs17782313); C_2084765_20 (ADRB2-rs1042714); C_2310403_10 (APÖA5-rs662799); C_2184734_10 (GNB3-rs5443) (Thermo Fisher Scientific, Inc., Waltham, MA, USA).

The following probe sequences were used in each respective genotyping assay: i) rs7566605 (near INSIG2) consensus sequence-Chr2: 118078449 on GrCH38: 5-AAGTACTTA ACAATGGATATTTGAT[C/G]GTGGTCCTTTAGGTCTG TACCAGGG-3'; ii) rs17782313 (MC4R) consensus sequence-Chr18:60183864 on GrCH38:5'-GTTTAAAGCAGG AGAGATTGTATCC[C/T]GATGGAAATGACAAGAAAA GCTTCA-3'; iii) rs1042714 (ADRB2) consensus sequence-Chr5: 148826910 on GrCH38: 5'-TGCGCCGGAC CACGACGTCACGCAG[C/G]AAAGGGACGAGGTGTGG GTGGTGGG-3'; iv) rs662799 (APOA5) consensus sequence-Chr11: 116792991 on GrCH38: 5'-GAGCCCCAGG AACTGGAGCGAAAGT[A/G]AGATTTGCCCCATGAGG AAAAGCTG-3'; and v) rs5443 (GNB3) consensus sequence-Chr12:6845711 on GrCH38: 5'-AGAGCATCATCT GCGGCATCACGTC[C/T]GTGGCCTTCTCCCTCAGTGG CCGCC-3'.

The two probes for each locus were identical apart from the region highlighted in square brackets, where the nucleotide in this position differed between the two probes, as indicated.

Quantitative polymerase chain reactions (PCR) were performed with two allele-specific TaqMan MGB probes for each of the five SNPs tested on an ABI 7,500 Real-Time PCR instrument. Duplicate reactions were run for each assay using a $25 \mu 1$ reaction volume on a 96-well plate. PCR was performed with $20 \mathrm{ng}$ input DNA, $1 \mu \mathrm{mol} / 1$ each primer, $0.25 \mu \mathrm{mol} / 1$ each probe and $1 \mathrm{x}$ TaqMan master mix (cat no. 4371355; Thermo Fisher Scientific, Inc., Waltham, MA, USA). The cycling program was one cycle of $50^{\circ} \mathrm{C}$ for $2 \mathrm{~min}$, one cycle of $95^{\circ} \mathrm{C}$ for $10 \mathrm{~min}$, followed by 40 cycles of $95^{\circ} \mathrm{C}$ for $15 \mathrm{sec}$ and $60^{\circ} \mathrm{C}$ for $1 \mathrm{~min}$. The ROX passive reference provides an internal reference to which the reporter-dye signal can be normalized during data analysis. The Taqman master mix contained AmpliTaq Gold ${ }^{\circledR}$ DNA Polymerase, Ultra Pure (UP) Deoxyribonucleotide triphosphates (dNTPs), ROX passive reference and buffer components optimized for tight endpoint fluorescence clusters, reproducible allelic discrimination and bench top stability. Fluorescence intensities (arbitrary units) of the two probes were plotted and genotype calling was performed using predefined calling parameters.

Statistical analysis. The SNPassoc package (https://CRAN.R-project.org/package=SNPassoc) in R (version 1.9-2) was employed to examine the association between global DNA methylation and five energy balance and lipid metabolism-associated loci. $\mathrm{R}$ is a language and environment for statistical computing and graphics, which is similar to the $\mathrm{S}$ language and environment (https://www.r-project.org/about.html).

Univariate and multivariate analyses were performed to investigate the association between each SNP and global DNA methylation adjusting for sex, age, weight, BMI and weight loss using the association function in the SNPassoc package in $\mathrm{R}$. This function carries out an association analysis between a single SNP and a dependent variable (phenotype) under five different genetic models (inheritance patterns): co-dominant, dominant, recessive, over-dominant and log-additive. The only significant association between global DNA methylation and an SNP, adjusted by BMI and weight loss, was obtained when using the $\log$ additive model. $\mathrm{P}<0.05$ was considered to indicate a statistically significant difference. All samples were analyzed in duplicate.

\section{Results}

Participant characteristics. The characteristics of the study participants are listed in Table II. The majority of the participants were females $(57 \%)$. The average age of males and females was 45 and 42 years old, respectively. The obese to overweight ratio among males $(73 \%$ obese and $27 \%$ overweight) was different to that observed for female participants (61\% obese and $39 \%$ overweight). The mean age was 43.5 years old with a standard error of the mean (SEM) of 1.29 , the median age was 45 years old, the age range was 11-67 years old and the interquartile range was 15 . The mean weight was $85.6 \mathrm{~kg}$ with a SEM of 1.89 , the median weight was $84.8 \mathrm{~kg}$, the weight range was $55-139 \mathrm{~kg}$ and the interquartile range was 25.3 . The mean height was $167.5 \mathrm{~cm}$ with a SEM of 0.92, the median height was $166 \mathrm{~cm}$, the height range was $149-139 \mathrm{~cm}$ and the interquartile range was 25.3 . The mean weight loss was $11.4 \mathrm{~kg}$ with a SEM of 1.02 , the median 
Table II. Patient characteristics in DNA methylation study that examined the association between global DNA methylation levels and SNPs.

\begin{tabular}{|c|c|}
\hline \multicolumn{2}{|l|}{ Sex } \\
\hline $\mathrm{F}(\%)$ & $60(57 \%)$ \\
\hline \multicolumn{2}{|l|}{ Age } \\
\hline$<34$ & 23 \\
\hline $35-39$ & 8 \\
\hline $40-44$ & 21 \\
\hline $45-49$ & 23 \\
\hline $50+$ & 30 \\
\hline Mean (SEM) & $43.5(1.29)$ \\
\hline Median (range) & $45(11-67)$ \\
\hline Interquartile range & 15 \\
\hline \multicolumn{2}{|l|}{ Weight (kilograms) } \\
\hline Mean (SEM) & $85.6(1.89)$ \\
\hline Median (range) & $84.8(55-139)$ \\
\hline Interquartile range & 25,3 \\
\hline \multicolumn{2}{|l|}{ Height (centimeters) } \\
\hline Mean (SE) & $167.5(0.92)$ \\
\hline Median (range) & $166(149-190)$ \\
\hline Interquartile range & 15 \\
\hline \multicolumn{2}{|c|}{ Weight loss (kilograms) } \\
\hline Mean (SE) & $11.4(1.02)$ \\
\hline Median (range) & $10(0-54)$ \\
\hline Interquartile range & 9 \\
\hline \multicolumn{2}{|l|}{ BMI } \\
\hline Mean (SE) & $30.1(0.68)$ \\
\hline Median (range) & $30(17-47)$ \\
\hline Interquartile range & 7 \\
\hline \multicolumn{2}{|l|}{ Diet } \\
\hline Yes $(\%)$ & $82(78)$ \\
\hline No $(\%)$ & $22(21)$ \\
\hline Unknown $(\%)$ & $1(1)$ \\
\hline
\end{tabular}

weight loss was $12 \mathrm{~kg}$, the range of weight loss observed was $0-64 \mathrm{~kg}$ and the interquartile range was 9 . The mean BMI was 30.1 with a SEM of 0.68, the median BMI was 30 , the BMI range was 17-47 and the interquartile range was 7 . Furthermore, substantial weight loss was observed across the study (median average, $12 \mathrm{~kg}$ ) however, marginally higher weight loss was observed in female (median average, $13 \mathrm{~kg}$ ) compared with male participants (median average, $12 \mathrm{~kg}$ ). BMI within the obese range was 30 on average, with a difference of 2 points between an average BMI of 29 for females and 31 for males.

Associations between GDMI values and loci associated with energy balance and lipid metabolism. The present study did not identify any associations between global DNA methylation and weight at baseline, BMI, sex or age (data not shown). However, an inverse association between global DNA methylation and weight loss $(\mathrm{P}<0.05$; Fig. 1) was demonstrated.
Furthermore, significant associations between the GDMI and INSIG2, after adjusting for BMI and weight loss $(\mathrm{P}<0.05)$, and significant trends when stratifying by gender $(\mathrm{P}<0.05)$ were also observed (data not shown). The frequency of genotypes for near INSIG2 (rs7566605; 50.53, 41.05 and $8.42 \%$ for GG, GC and CC, respectively) and the boxplots for INSIG2 genotype and their corresponding GDMI values are presented in Fig. 2. No significant associations between global DNA methylation and the other genes were observed (data not shown). The frequency of genotypes for the other four genes were as follows: ADRB2 (rs1042714), 50.53, 34.74 and $14.74 \%$ for CC, CG and GG, respectively; APOA5 (rs662799), 88.42, 10.53 and $1.05 \%$ for AA, AG and GG, respectively; GNB3 (rs5443), 41.05, 50.53 and $8.42 \%$ for CC, CT and TT, respectively; and MC4R (rs17782313), 97.89, 1.05 and $1.05 \%$ for GG, AG and AA, respectively (Table III). Boxplots of GDMI values stratified by genotype for $A D R B 2, G N B 3, A P O A 5$ and $M C 4 R$ are presented in Fig. 3.

\section{Discussion}

The present study demonstrated an inverse association between global DNA methylation and weight loss; as weight loss increased, global DNA methylation decreased. However, no associations between global DNA methylation and weight at baseline, BMI, sex or age were observed. Therefore, global DNA methylation may have potential as a marker for weight loss potential from personalized weight reduction programs based on genotypic profiles. The association between near INSIG2 (rs7566605) and global DNA methylation indicates that genetic variants may interact with epigenetic events that are ultimately associated with weight loss potential. The present study investigated the association between global DNA methylation and the allelic composition of five genetic loci associated with energy balance and lipid metabolism, and weight loss among participants, in a personalized weight reduction program designed on the basis of genotypic information. These five loci, near INSIG2 (rs7566605), MC4R (rs17782313), ADRB2 (rs1042714), APOA5 (rs662799) and GNB3 (rs5443), are among the most well-characterized SNPs regarding their roles in obesity, energy balance and lipid metabolism.

INSIG2 is located at $2 \mathrm{q} 14.2$. The protein product of this gene has a high degree of similarity with the protein encoded by INSIG1, both of which are endoplasmic reticulum proteins that inhibit sterol regulatory element binding proteins (SREBP) processing. INSIG1/2 impair the processing of SREBPs as they bind to SREBP cleavage-activating protein (SCAP), which prevents SCAP from assisting the transport of SREBPs to the Golgi apparatus. Variations in INSIG2 are reported to be associated with weight gain in certain ethnic subgroups $(43,67)$. The SNP that was investigated in the present study, which is in close proximity to INSIG2, is present in $10 \%$ of the population and predisposes to the development of obesity in the general population. The CC single SNP predisposes to the development of obesity, is associated with a higher BMI and increases the probability of developing obesity by $40 \%$ (44-46). MC $4 R$ is located at $18 \mathrm{q} 22$. The protein product of this gene is a membrane-bound receptor and a member of the melanocortin receptor family. 


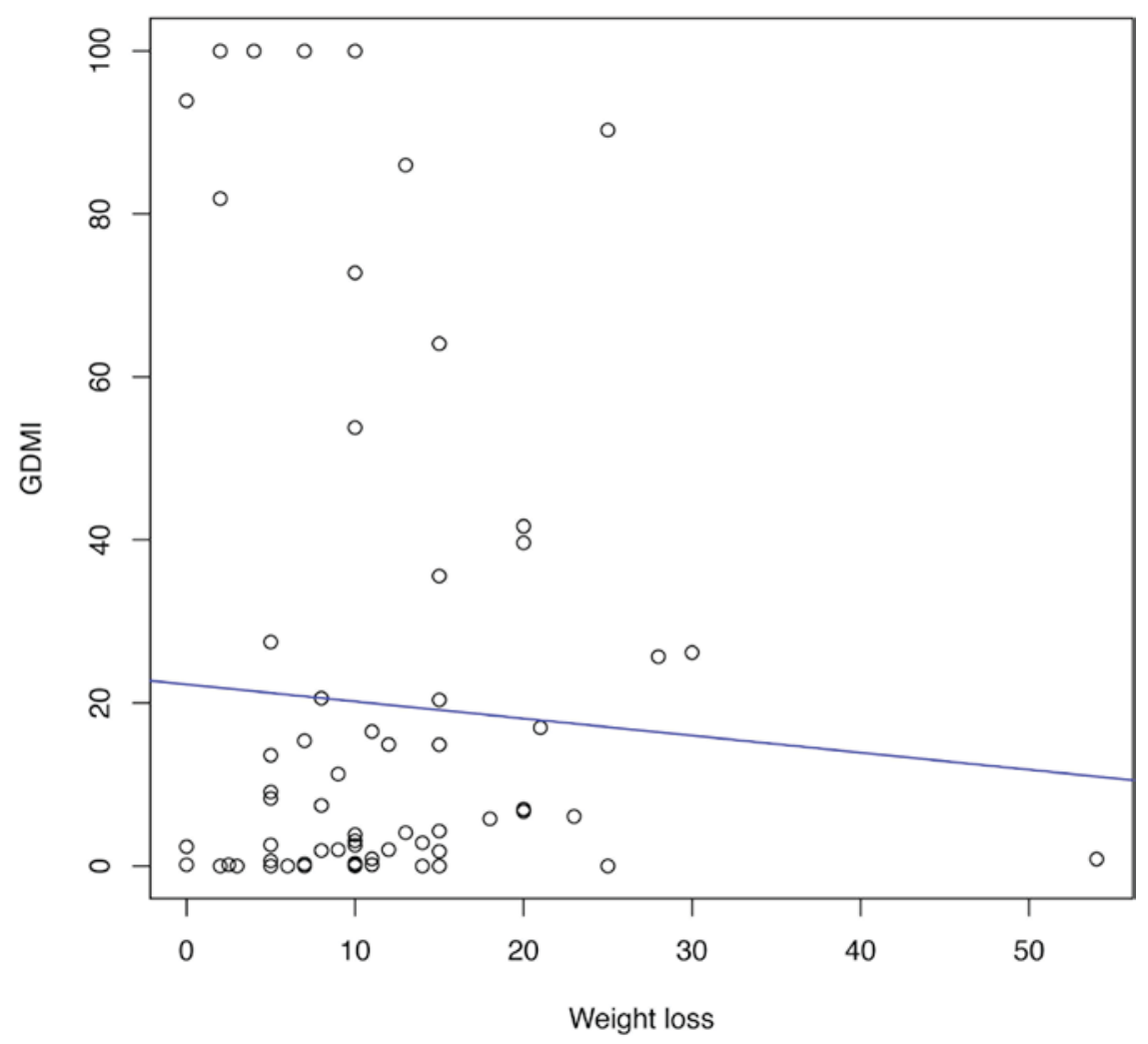

Figure 1. Inverse association between global DNA methylation and weight loss $(\mathrm{P}<0.05)$.

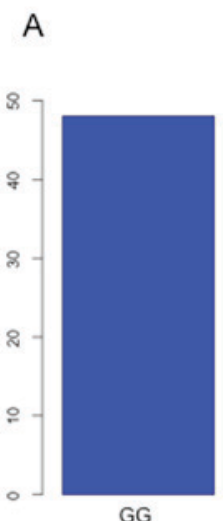

GG

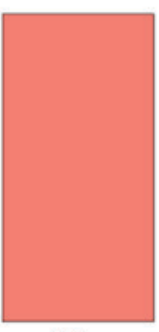

GC
$\mathrm{CC}$

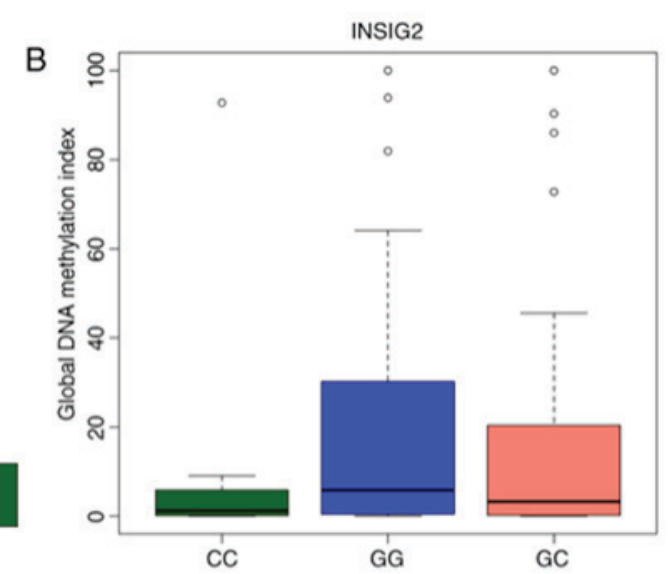

\section{Genotypes \\ Frequency percentage \\ GG $48 \quad 50.53 \%$ \\ GC $39 \quad 41.05 \%$ \\ CC $8 \quad 8.42 \%$}

Figure 2. (A) The allelic frequency of near INSIG2 (rs7566605) was 50.53, 41.05 and $8.42 \%$ for G/G, G/C and C/C, respectively. (B) Boxplots for each near INSIG2 (rs7566605) genotype and their corresponding global DNA methylation index values. INSIG2, insulin-induced gene 2.

$M C 4 R$ is primarily expressed in the central nervous system in areas where energy intake is controlled. The absence of this receptor leads to hyperphagia, hyperinsulinemia and obesity. The protein interacts with adrenocorticotropic and melanocyte-stimulating hormones, and is mediated by G-proteins. Variations in this gene are thought to be associated with waist circumference and insulin resistance, fat mass and obesity $(47,48)$. Heterozygotes (CT) and homozygotes
(TT) exhibit a higher energy expenditure, increased glucose oxidation, reduced levels of free fatty acids, a lower BMI and almost half the probability of developing obesity. For these reasons, $M C 4 R$ variants are considered to be protective factors in obesity $(49,50,68,69)$.

$A D R B 2$ is located at $5 \mathrm{q} 31-\mathrm{q} 32$. This gene encodes the $\beta 2$-adrenergic receptor, which is a member of the $\mathrm{G}$-protein-coupled receptor superfamily. $A D R B 2$ has an 
Table III. Frequency and percentage of alleles and genotypes at five loci associated with energy balance and lipid metabolism in study participants.

A, Frequency and percentage of alleles for each locus in study participants

\begin{tabular}{lrc}
\hline Gene (SNP) and variants & Frequency & Percentage \\
\hline ADRB2 (rs1042714) & 129 & \\
$\mathrm{C}$ & 61 & 67.89 \\
$\mathrm{G}$ & & 32.11 \\
APOA5 (rs662799) & 178 & \\
$\mathrm{~A}$ & 12 & 93.68 \\
$\mathrm{G}$ & & 6.32 \\
GNB3 (rs5443) & 126 & \\
$\mathrm{C}$ & 64 & 66.32 \\
$\mathrm{~T}$ & & 33.68 \\
$\mathrm{Near} I N S I G 2$ (rs7566605) & 135 & \\
$\mathrm{G}$ & 55 & 28.95 \\
$\mathrm{C}$ & & \\
$M C 4 R(\mathrm{rs} 17782313)$ & 187 & 98.42 \\
$\mathrm{C}$ & 3 & 1.58 \\
$\mathrm{~T}$ & &
\end{tabular}

B, Frequency and percentage of genotypes for each locus in study participants

\begin{tabular}{lrr}
\hline Gene (SNP) and variants & Frequency & Percentage \\
\hline ADRB2 (rs1042714) & & \\
CC & 48 & 50.53 \\
CG & 14 & 34.74 \\
GG & & 14.74 \\
APOA5 (rs662799) & 84 & \\
AA & 10 & 88.42 \\
AG & 1 & 10.53 \\
GG & & 1.05 \\
GNB3 (rs5443) & 39 & \\
CC & 48 & 41.05 \\
CT & 8 & 50.53 \\
TT & & 8.42 \\
Near INSIG2 (rs7566605) & 48 & \\
GG & 39 & 50.53 \\
GC & 8 & 41.05 \\
CC & & 8.42 \\
MC4R (rs17782313) & 1.05 \\
CC & & \\
TC & & 97.89 \\
TT & & \\
\hline
\end{tabular}

SNP, single nucleotide polymorphism; $A D R B 2$, adrenoceptor $\beta 2$; $A P O A 5$, apolipoprotein A5; GNB3, G-protein subunit $\beta 3$; INSIG2, insulin-induced gene 2; $M C 4 R$, melanocortin 4 receptor. important role in the regulation of energy balance as it leads to increases in lipolysis and thermogenesis (51). Variants in $A D R B 2$ are associated with obesity, chronic obstructive pulmonary disease and responses to asthma treatment (70-72). The ADRB2 rs1042714 polymorphism was reported to regulate diet-induced alterations in body weight and composition; women with the $\mathrm{CG}$ variant that consumed diets rich in carbohydrates exhibited a 2.5 -fold higher risk of developing obesity (52). Furthermore, the ADRB2 rs1042714 allele is reported to be associated with increased BMI, body fat mass, fat cell volume and waist: hip ratio, in addition to associations with type II diabetes and the inhibition of lipid oxidation (54,55,73-75).

APOA5 is located at chromosome 11q23. This protein is an apolipoprotein that is involved in the regulation of plasma triglyceride levels, is associated with the levels of high-density lipoprotein cholesterol and the susceptibility to coronary artery disease $(56,57,76,77)$. It is a component of high-density lipoprotein and accelerates the catalysis of low-density lipoprotein via the activation of the lipase protein. APOA5 enhances the catabolism of triglyceride-rich lipoproteins and reduces the production of very low-density lipoprotein, which is the primary triglyceride carrier. The presence of one of its variants in heterozygosity (AG variant) or homozygosity (GG variant) is associated with an increased risk of cardiovascular disease and metabolic syndrome, which may lead to the development of diabetes and obesity (58-60,78). Additionally, the rs662799 SNP of APOA5, which was included in the present study, was associated with weight loss following short-term dieting (61).

GNB3 is located at $12 \mathrm{p} 13$. This gene is a heterotrimeric guanine nucleotide-binding protein and is also a member of the $\mathrm{G}$ protein-coupled receptor superfamily. The GNB3 SNP rs5443 was reported to be a predictor of successful weight loss under sibutramine therapy (62). This variant has also been associated with various metabolic conditions, including obesity, coronary artery disease, insulin resistance and diabetes, and hypertension. Female carriers of the TT variant were reported to have a 6 -fold higher risk of becoming overweight in the postpartum period, though the risk was markedly reduced in women who exercised regularly $(63-65,79,80)$. In addition, associations between rs5443 and patient responses to sildenafil have been reported $(81,82)$.

Epigenetic alterations occur over time and throughout the lifetime of individuals. Examples of these alterations include DNA methylation $(83,84)$ and histone modifications $(85,86)$, which are associated with factors such as diet (87), stress (88) and other modifiable lifestyles, including smoking (89) and alcohol consumption (90). Global DNA methylation levels, measured in PBMCs with Long Interspersed Nucleotide Elements-1 (LINE)-1 as a surrogate endpoint, was reported to be significantly higher in participants with a higher degree of weight loss compared with those who exhibited low responses $(<8 \%)$ to energy-restricted treatment (91). LINE-1 was reported to be positively associated with healthy energy and micronutrient intake, and inversely associated with body fat mass (92).

It has been demonstrated that weight loss induced by a hypocaloric diet in humans altered the DNA methylation status of certain genes. Baseline DNA methylation patterns 
A

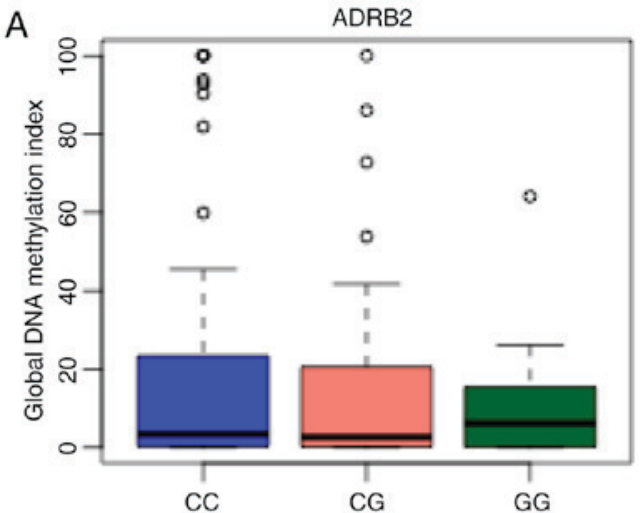

$\mathrm{C}$

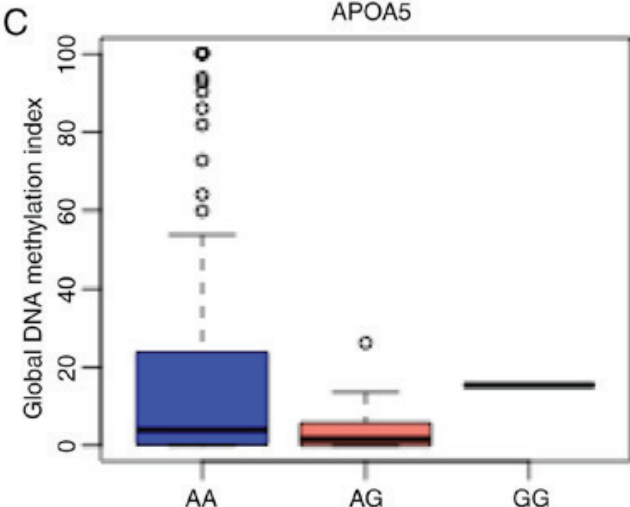

B

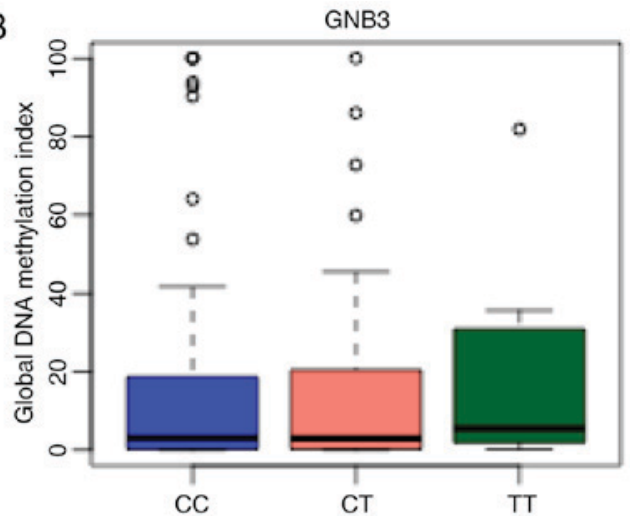

D

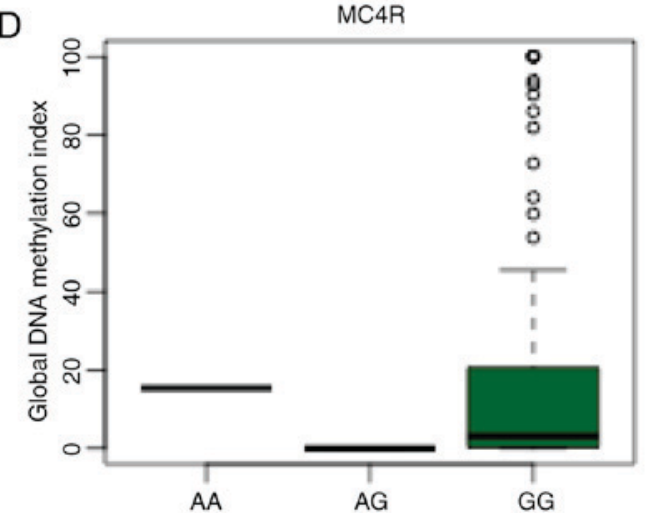

Figure 3. Boxplots of global DNA methylation index values stratified by genotype for (A) ADRB2, (B) GNB3, (C) APOA5 and (D) MC4R. ADRB2, adrenoceptor $\beta 2 ; G N B 3$, G-protein subunit $\beta 3 ; A P O A 5$, apolipoprotein A5; $M C 4 R$, melanocortin 4 receptor.

have previously been employed as epigenetic markers that may allow the degree of weight loss to be predicted in obese patients (52). In another study, epigenetic scores were used to predict alterations in body weight (7), and also identified five genes (aquaporin 9, dual specificity phosphatase 22, homeodomain-interacting protein kinase 3 , troponin T1 slow skeletal type and troponin $\mathrm{I} 3$ cardiac type) that were differentially methylated between participants with high and low responses to a weight loss intervention program. The study also reported that subjects with the highest methylation in these regions exhibited a significantly enhanced response to the weight loss treatment program. While these studies demonstrate that differential methylation at specific loci may have an effect on weight loss, the results of the present study also demonstrate that global differential DNA methylation may also be associated with weight loss.

Global and gene-specific DNA methylation alterations, which vary with age, sex and socioeconomic status, may also be predictive biomarkers of weight loss response to intervention programs (91). Global DNA methylation and inflammatory gene promoter hypermethylation are reported to be early biomarkers of adiposity and metabolic alterations (93). Global DNA methylation and hydroxymethylation may functions as biomarkers in obesity and associated comorbidities. DNA methylation patterns are reported to behave differently depending on the choice of intervention in obesity (diet or surgery) (94).

The major strength of the present study is the simultaneous analysis of SNP loci and DNA methylation in the context of weight loss in obese patients. Interactions between germline variants of genes with somatic changes in epigenetic modifications may provide insights into pathologic causality in obesity and weight loss. The present study also demonstrates that non-invasive methods of assaying molecular biomarkers, such as those employed in the current study, may translate well in the clinic. Additionally, as global DNA methylation does not appear to be associated with initial BMI, initial weight, sex or age, further studies of this type should consider including additional weight-associated variable measurements that may be associated with global and gene-specific DNA methylation levels.

The results of the current study indicate that precision weight loss programs designed based on genetic and epigenetic information, which involve the creation of personalized interventions for individuals, may be beneficial for obese patients $(95,96)$. These personalized programs may incorporate data from previous studies that have identified associations between DNA methylation, diet and weight loss. At present, is difficult to interpret how the interaction between INSIG2 and global DNA methylation modulates the weight loss response. Therefore, additional studies should consider the concurrent associations of established and unknown energy balance and lipid metabolism SNPs to improve the understanding of the role of DNA methylation in obesity and the weight loss responses.

\section{Acknowledgements}

The present study was supported by the National Cancer Institute (grant nos. K01-CA164092 and U01-CA8498). 


\section{References}

1. Jiang Y, Chen Y, Manuel D, Morrison H and Mao Y; Obesity Working Group: Quantifying the impact of obesity category on major chronic diseases in Canada. ScientificWorldJournal 7: $1211-1221,2007$.

2. Huxley R, James WP, Barzi F, Patel JV, Lear SA, Suriyawongpaisal P, Janus E, Caterson I, Zimmet P, Prabhakaran D, et al: Ethnic comparisons of the cross-sectional relationships between measures of body size with diabetes and hypertension. Obes Rev 9 (Suppl 1): S53-S61, 2008

3. Obesity in Asia Collaboration: Is central obesity a better discriminator of the risk of hypertension than body mass index in ethnically diverse populations? J Hypertens 26: 169-177, 2008

4. Goni L, Milagro FI, Cuervo M and Martínez JA: Single-nucleotide polymorphisms and DNA methylation markers associated with central obesity and regulation of body weight. Nutr Rev 72 : 673-690, 2014

5. Lau DC, Douketis JD, Morrison KM, Hramiak IM, Sharma AM and Ur E; Obesity Canada Clinical Practice Guidelines Expert Panel: 2006 Canadian clinical practice guidelines on the management and prevention of obesity in adults and children (summary). CMAJ 176: S1-S13, 2007.

6. Stroh C, Köckerling F, Weiner R, Horbach T, Ludwig K, Dressler M, Lange V, Loermann P, Wolff S, Schmidt U, et al: Are there gender-specific aspects of sleeve gastrectomy-data analysis from the quality assurance study of surgical treatment of obesity in Germany. Obes Surg 22: 1214-1219, 2012.

7. Moleres A, Campión J, Milagro FI, Marcos A, Campoy C, Garagorri JM, Gómez-Martínez S, Martínez JA, Azcona-Sanjulián MC and Martí A; EVASYON Study Group: Differential DNA methylation patterns between high and low responders to a weight loss intervention in overweight or obese adolescents: The EVASYON study. FASEB J 27: 2504-2512, 2013

8. Bouchard L, Rabasa-Lhoret R, Faraj M, Lavoie ME, Mill J, Pérusse L and Vohl MC: Differential epigenomic and transcriptomic responses in subcutaneous adipose tissue between low and high responders to caloric restriction. Am J Clin Nutr 91: 309-320, 2010

9. Mansego ML, Milagro FI, Zulet MA and Martinez JA: SH2B1 CpG-SNP is associated with body weight reduction in obese subjects following a dietary restriction program. Ann Nutr Metab 66: 1-9, 2015

10. van Dijk SJ, Tellam RL, Morrison JL, Muhlhausler BS and Molloy PL: Recent developments on the role of epigenetics in obesity and metabolic disease. Clin Epigenetics 7: 66, 2015.

11. Campión J, Milagro FI, Goyenechea E and Martínez JA: TNF-alpha promoter methylation as a predictive biomarker for weight-loss response. Obesity (Silver Spring) 17: 1293-1297, 2009

12. Wang K, Li WD, Zhang CK, Wang Z, Glessner JT, Grant SF, Zhao $\mathrm{H}$, Hakonarson $\mathrm{H}$ and Price RA: A genome-wide association study on obesity and obesity-related traits. PLoS One 6: e18939, 2011.

13. Mansego ML, Garcia-Lacarte M, Milagro FI, Marti A and Martinez JA; GENOI members: DNA methylation of miRNA coding sequences putatively associated with childhood obesity. Pediatr Obes 12: 19-27, 2017

14. van Dijk SJ, Molloy PL, Varinli H, Morrison JL and Muhlhausler BS; Members of EpiSCOPE: Epigenetics and human obesity. Int J Obes (Lond) 39: 85-97, 2015.

15. Youngson NA and Morris MJ: What obesity research tells us about epigenetic mechanisms. Philos Trans R Soc Lond B Biol Sci 368: 20110337, 2013.

16. Na YK, Hong HS, Lee DH, Lee WK and Kim DS: Effect of body mass index on global DNA methylation in healthy Korean women. Mol Cells 37: 467-672, 2014.

17. Nomura Y, Lambertini L, Rialdi A, Lee M, Mystal EY, Grabie M, Manaster I, Huynh N, Finik J, Davey M, et al: Global methylation in the placenta and umbilical cord blood from pregnancies with maternal gestational diabetes, preeclampsia, and obesity. Reprod Sci 21: 131-137, 2014

18. BLUEPRINT consortium: Quantitative comparison of DNA methylation assays for biomarker development and clinical applications. Nat Biotechnol 34: 726-737, 2016.

19. Crary-Dooley FK, Tam ME, Dunaway KW, Hertz-Picciotto I Schmidt RJ and LaSalle JM: A comparison of existing global DNA methylation assays to low-coverage whole-genome bisulfite sequencing for epidemiological studies. Epigenetics 12: 206-214, 2017.
20. Perng W, Mora-Plazas M, Marín C, Rozek LS, Baylin A and Villamor E: A prospective study of LINE-1DNA methylation and development of adiposity in school-age children. PLoS One 8: e62587, 2013.

21. Pearce MS, McConnell JC, Potter C, Barrett LM, Parker L, Mathers JC and Relton CL: Global LINE-1 DNA methylation is associated with blood glycaemic and lipid profiles. Int J Epidemiol 41: 210-217, 2012.

22. Duggan C, Xiao L, Terry MB and McTiernan A: No effect of weight loss on LINE-1 methylation levels in peripheral blood leukocytes from postmenopausal overweight women. Obesity (Silver Spring) 22: 2091-2096, 2014.

23. Demerath EW, Guan W, Grove ML, Aslibekyan S, Mendelson M, Zhou YH, Hedman ÅK, Sandling JK, Li LA, Irvin MR, et al: Epigenome-wide association study (EWAS) of BMI, BMI change and waist circumference in African American adults identifies multiple replicated loci. Hum Mol Genet 24: 4464-4479, 2015.

24. Aslibekyan S, Demerath EW, Mendelson M, Zhi D, Guan W, Liang L, Sha J, Pankow JS, Liu C, Irvin MR, et al: Epigenome-wide study identifies novel methylation loci associated with body mass index and waist circumference. Obesity (Silver Spring) 23: 1493-1501, 2015.

25. Dick KJ, Nelson CP, Tsaprouni L, Sandling JK, Aïssi D, Wahl S, Meduri E, Morange PE, Gagnon F, Grallert H, et al: DNA methylation and body-mass index: A genome-wide analysis. Lancet 383: 1990-1998, 2014.

26. Kaz AM, Wong CJ, Varadan V, Willis JE, Chak A and Grady WM: Global DNA methylation patterns in Barrett's esophagus, dysplastic Barrett's and esophageal adenocarcinoma are associated with BMI, gender, and tobacco use. Clin Epigenetics 8: 111, 2016.

27. Lillycrop K, Murray R, Cheong C, Teh AL, Clarke-Harris R, Barton S, Costello P, Garratt E, Cook E, Titcombe P, et al: ANRIL promoter DNA methylation: A perinatal marker for later adiposity. EBioMedicine 19: 60-72, 2017.

28. Lumey LH, Terry MB, Delgado-Cruzata L, Liao Y, Wang Q Susser E, McKeague I and Santella RM: Adult global DNA methylation in relation to pre-natal nutrition. Int J Epidemiol 41: 116-123, 2012.

29. Tobi EW, Slieker RC, Stein AD, Suchiman HE, Slagboom PE, van Zwet EW, Heijmans BT and Lumey LH: Early gestation as the critical time-window for changes in the prenatal environment to affect the adult human blood methylome. Int J Epidemiol 44: 1211-1223, 2015

30. Tobi EW, Goeman JJ, Monajemi R, Gu H, Putter H, Zhang Y, Slieker RC, Stok AP, Thijssen PE and Müller F: DNA methylation signatures link prenatal famine exposure to growth and metabolism. Nat Commun 5: 5592, 2014.

31. Agha G, Hajj H, Rifas-Shiman SL, Just AC, Hivert MF, Burris HH, Lin X, Litonjua AA, Oken E, DeMeo DL, et al: Birth weight-for-gestational age is associated with DNA methylation at birth and in childhood. Clin Epigenetics 8: 118, 2016.

32. Kupers LK, Xu X, Jankipersadsing SA, Vaez A, la Bastide-van Gemert S, Scholtens S, Nolte IM, Richmond RC, Relton CL, Felix JF, et al: DNA methylation mediates the effect of maternal smoking during pregnancy on birthweight of the offspring. Int J Epidemiol 44: 1224-1237, 2015.

33. Kresovich JK, Zheng Y, Cardenas A, Joyce BT, Rifas-Shiman SL, Oken E, Gillman MW, Hivert MF, Baccarelli AA and Hou L: Cord blood DNA methylation and adiposity measures in early and mid-childhood. Clin Epigenetics 9: 86, 2017.

34. Godfrey KM, Sheppard A, Gluckman PD, Lillycrop KA, Burdge GC, McLean C, Rodford J, Slater-Jefferies JL, Garratt E, Crozier SR, et al: Epigenetic gene promoter methylation at birth is associated with child's later adiposity. Diabetes 60: 1528-34, 2011.

35. Richmond SA, Rothman L, Buliung R, Schwartz N, Larsen K and Howard A: Exploring the impact of a dedicated streetcar right-of-way on pedestrian motor vehicle collisions: A quasi experimental design. Accid Anal Prev 71: 222-227, 2014.

36. Stel J and Legler J: The role of epigenetics in the latent effects of early life exposure to obesogenic endocrine disrupting chemicals. Endocrinology 156: 3466-3472, 2015.

37. Do C, Shearer A, Suzuki M, Terry MB, Gelernter J, Greally JM and Tycko B: Genetic-epigenetic interactions in cis: A major focus in the post-GWAS era. Genome Biol 18: 120, 2017.

38. Do C,Lang CF, Lin J, Darbary H, Krupska I, Gaba A, Petukhova L, Vonsattel JP, Gallagher MP, Goland RS, et al: Mechanisms and disease associations of haplotype-dependent allele-specific DNA methylation. Am J Hum Genet 98: 934-955, 2016. 
39. Cole SA: Epigenetic studies of perinatal determinants of later obesity link important, but previously unrelated, genetic and epidemiological findings. EBioMedicine 20: 15-16, 2017.

40. Day SE, Coletta RL, Kim JY, Garcia LA, Campbell LE, Benjamin TR, Roust LR, De Filippis EA, Mandarino LJ and Coletta DK: Potential epigenetic biomarkers of obesity-related insulin resistance in human whole-blood. Epigenetics 12: 254-263.

41. Aronica L, Levine AJ, Brennan K, Mi J, Gardner C, Haile RW and Hitchins MP: A systematic review of studies of DNA methylation in the context of a weight loss intervention. Epigenomics 9: 769-787, 2017.

42. den Dunnen JT, Dalgleish R, Maglott DR, Hart RK, Greenblatt MS, McGowan-Jordan J, Roux AF, Smith T, Antonarakis SE and Taschner PE: HGVS recommendations for the description of sequence variants: 2016 update. Hum Mutat 37: 564-569, 2016

43. Le Hellard S, Theisen FM, Haberhausen M, Raeder MB, Fernø J, Gebhardt S, Hinney A, Remschmidt H, Krieg JC, Mehler-Wex C, et al: Association between the insulin-induced gene 2 (INSIG2) and weight gain in a German sample of antipsychotic-treated schizophrenic patients: Perturbation of SREBP-controlled lipogenesis in drug-related metabolic adverse effects? Mol Psychiatry 14: 308-317, 2009.

44. Prakash J, Mittal B, Apurva S, Shally A, Pranjal S and Neena S: Common genetic variant of insig2 gene rs7566605 polymorphism is associated with severe obesity in north India. Iran Biomed J 21: 261-269, 2017.

45. Apalasamy YD, Moy FM, Rampal S, Bulgiba A and Mohamed Z: Genetic associations of the INSIG2 rs7566605 polymorphism with obesity-related metabolic traits in malaysian malays. Genet Mol Res 13: 4904-10, 2014

46. Kaulfers AM, Deka R, Dolan L and Martin LJ: Association of INSIG2 polymorphism with overweight and LDL in children. PLoS One 10: e0116340, 2015.

47. Chambers JC, Elliott P, Zabaneh D, Zhang W, Li Y, Froguel P, Balding D, Scott J and Kooner JS: Common genetic variation near MC4R is associated with waist circumference and insulin resistance. Nat Genet 40: 716-718, 2008

48. Loos RJ, Lindgren CM, Li S, Wheeler E, Zhao JH, Prokopenko I, Inouye M, Freathy RM, Attwood AP, Beckmann JS, et al: Common variants near MC4R are associated with fat mass, weight and risk of obesity. Nat Genet 40 : 768-775, 2008

49. Xi B, Chandak GR, Shen Y, Wang Q and Zhou D: Association between common polymorphism near the MC4R gene and obesity risk: A systematic review and meta-analysis. PLoS One 7: e45731.

50. Paolini B, Maltese PE, Del Ciondolo I, Tavian D, Missaglia S, Ciuoli C, Zuntini M, Cecchin S, Bertelli M and Pompucci G: Prevalence of mutations in LEP, LEPR and MC4R genes in individuals with severe obesity. Genet Mol Res 15, 2016.

51. Takenaka A, Nakamura S, Mitsunaga F, Inoue-Murayama M, Udono T and Suryobroto B: Human-specific SNP in obesity genes, adrenergic receptor beta2 (ADRB2), Beta3 (ADRB3) and PPAR $\gamma 2$ (PPARG), during primate evolution. PLoS One 7: e43461, 2012.

52. Ruiz JR, Larrarte E, Margareto J, Ares R and Labayen I: Role of $\beta_{2}$-adrenergic receptor polymorphisms on body weight and body composition response to energy restriction in obese women: Preliminary results. Obesity (Silver Spring) 19: 212-215, 2011.

53. Ruiz JR, Larrarte E, Margareto J, Ares R, Alkorta P and Labayen I: Preliminary findings on the role of PLIN1 polymorphisms on body composition and energy metabolism response to energy restriction in obese women. Br J Nutr 106: 486-90, 2011.

54. Large V, Hellström L, Reynisdottir S, Lönnqvist F, Eriksson P, Lannfelt L and Arner P: Human beta-2 adrenoceptor gene polymorphisms are highly frequent in obesity and associate with altered adipocy te beta-2 adrenoceptor function. J Clin Invest 100: 3005-3013, 1997.

55. Ishiyama-Shigemoto S, Yamada K, Yuan X, Ichikawa F and Nonaka K: Association of polymorphisms in the beta2-adrenergic receptor gene with obesity, hypertriglyceridaemia, and diabetes mellitus. Diabetologia 42: 98-101, 1999.

56. Martin S, Nicaud V, Humphries SE and Talmud PJ; EARS group: Contribution of APOA5 gene variants to plasma triglyceride determination and to the response to both fat and glucose tolerance challenges. Biochim Biophys Acta 1637: 217-225, 2003.
57. Kisfali P, Mohás M, Maasz A, Hadarits F, Markó L, Horvatovich K, Oroszlán T, Bagosi Z, Bujtor Z, Gasztonyi B, et al: Apolipoprotein A5 IVS3+476A allelic variant associates with increased trigliceride levels and confers risk for development of metabolic syndrome in Hungarians. Circ J 72: 40-43, 2008.

58. Elosua R, Ordovas JM, Cupples LA, Lai CQ, Demissie S, Fox CS, Polak JF, Wolf PA, D'Agostino RB Sr and O'Donnell CJ: Variants at the APOA5 locus, association with carotid atherosclerosis and modification by obesity: The Framingham Study. J Lipid Res 47: 990-996, 2006.

59. Sánchez-Moreno C, Ordovás JM, Smith CE, Baraza JC, Lee YC and Garaulet M: APOA5 gene variation interacts with dietary fat intake to modulate obesity and circulating triglycerides in a Mediterranean population. J Nutr 141: 380-385, 2011.

60. Garelnabi M, Lor K, Jin J, Chai F and Santanam N: The paradox of ApoA5 modulation of triglycerides: Evidence from clinical and basic research. Clin Biochem 46: 12-19, 2013.

61. Aberle J, Evans D, Beil FU and Seedorf U: A polymorphism in the apolipoprotein A5 gene is associated with weight loss after short-term diet. Clin Genet 68: 152-154, 2005.

62. Hauner H, Meier M, Jöckel KH, Frey UH and Siffert W: Prediction of successful weight reduction under sibutramine therapy through genotyping of the G-protein beta3 subunit gene (GNB3) C825T polymorphism. Pharmacogenetics 13: 453-459, 2003.

63. Hsiao TJ, Hwang Y, Liu CH, Chang HM and Lin E: Association of the C825T polymorphism in the GNB3 gene with obesity and metabolic phenotypes in a Taiwanese population. Genes Nutr 8: 137-144, 2013.

64. Maniotis C, Chantziara K, Kokkoris P, Papadogiannis D, Andreou C, Tsioufis C, Vaiopoulos G and Stefanadis C: The AGT and the GNB3 polymorphisms and insulin resistance in prehypertension. Hormones (Athens) 13: 79-86, 2014.

65. Michalsen A, Knoblauch NT, Lehmann N, Grossman P, Kerkhoff G, Wilhelm FH, Moebus S, Konstantinides S, Binder L and Heusch G: Effects of lifestyle modification on the progression of coronary atherosclerosis, autonomic function and angina-the role of GNB3 C825T polymorphism. Am Heart J 151: $870-877,2006$.

66. Hoque MO, Lee CC, Cairns P, Schoenberg M and Sidransky D: Genome-wide genetic characterization of bladder cancer: A comparison of high-density single-nucleotide polymorphism arrays and PCR-based microsatellite analysis. Cancer Res 63: 2216-2222, 2003

67. Smith AJ, Cooper JA, Li LK and Humphries SE: INSIG2 gene polymorphism is not associated with obesity in Caucasian, Afro-Caribbean and Indian subjects. Int J Obes (Lond) 31: 1753-1755, 2007

68. Granell S, Serra-Juhé C, Martos-Moreno GÁ, Díaz F, Pérez-Jurado LA, Baldini G and Argente J: A novel melanocortin-4 receptor mutation MC4R-P272L associated with severe obesity has increased propensity to be ubiquitinated in the ER in the face of correct folding. PLoS One 7: e50894, 2012.

69. Corella D, Ortega-Azorín C, Sorlí JV, Covas MI, Carrasco P, Salas-Salvadó J, Martínez-González MÁ, Arós F, Lapetra J, Serra-Majem L, et al: Statistical and biological gene-lifestyle interactions of MC4R and FTO with diet and physical activity on obesity: New effects on alcohol consumption. PLoS One 7: e52344, 2012

70. Feigelson HS, Teras LR, Diver WR, Tang W, Patel AV, Stevens VL, Calle EE, Thun MJ and Bouzyk M: Genetic variation in candidate obesity genes ADRB2, ADRB3, GHRL, HSD11B1, IRS1, IRS2 and SHC1 and risk for breast cancer in the cancer prevention study II. Breast Cancer Res 10: R57, 2008.

71. Brøgger J, Steen VM, Eiken HG, Gulsvik A and Bakke P: Genetic association between COPD and polymorphisms in TNF, ADRB2 and EPHX1. Eur Respir J 27: 682-688, 2006.

72. Park HW, Yang MS, Park CS, Kim TB, Moon HB, Min KU, Kim YY and Cho SH: Additive role of tiotropium in severe asthmatics and Arg16Gly in ADRB2 as a potential marker to predict response. Allergy 64: 778-783, 2009.

73. González Sánchez JL, Proenza AM, Martínez Larrad MT, Ramis JM, Fernández Pérez C, Palou A and Serrano Ríos M: The glutamine 27 glutamic acid polymorphism of the beta2-adrenoceptor gene is associated with abdominal obesity and greater risk of impaired glucose tolerance in men but not in women: A population-based study in Spain. Clin Endocrinol (Oxf) 59: 476-481, 2003. 
74. Kawaguchi H, Masuo K, Katsuya T, Sugimoto K, Rakugi H, Ogihara T and Tuck ML: Beta2- and beta3-Adrenoceptor polymorphisms relate to subsequent weight gain and blood pressure elevation in obese normotensive individuals. Hypertens Res 29: 951-959, 2006.

75. Masuo K, Katsuya T, Kawaguchi H, Fu Y, Rakugi H, Ogihara T and Tuck ML: Beta2-adrenoceptor polymorphisms relate to obesity through blunted leptin-mediated sympathetic activation. Am J Hypertens 19: 1084-1091, 2006.

76. Maasz A, Kisfali P, Jaromi L, Horvatovich K, Szolnoki Z, Csongei V, Safrany E, Sipeky C, Hadarits F and Melegh B: Apolipoprotein A5 gene IVS3+G476A allelic variant confers susceptibility for development of ischemic stroke. Circ J 72 : 1065-1070, 2008.

77. Maász A, Kisfali P, Szolnoki Z, Hadarits F and Melegh B Apolipoprotein A5 gene C56G variant confers risk for the development of large-vessel associated ischemic stroke. J Neurol 255 649-654, 2008

78. Elosua R, Cupples LA, Fox CS, Polak JF, D'Agostino RA Sr Wolf PA, O'Donnell CJ and Ordovas JM: Association between well-characterized lipoprotein-related genetic variants and carotid intimal medial thickness and stenosis: The framingham heart study. Atherosclerosis 189: 222-228, 2006.

79. Casiglia E, Tikhonoff V, Boschetti G, Bascelli A, Saugo M Guglielmi G, Caffi S, Rigoni G, Giordano N, Grasselli C, et al: The C825T GNB3 polymorphism, independent of blood pressure, predicts cerebrovascular risk at a population level. Am J Hypertens 25: 451-457, 2012.

80. Frey UH, Moebus S, Möhlenkamp S, Kälsch H, Bauer M, Lehmann N, Nöthen M, Mühleisen TW, Stang A and Erbel R, et al: GNB3 gene 825 TT variant predicts hard coronary events in the population-based HEINZ NIXDORF RECALL study. Atherosclerosis 237: 437-442, 2014.

81. Nishimura R, Tanabe N, Sekine A, Kasai H, Suda R, Kato F, Jujo T, Sugiura T, Shigeta A, Sakao S and Tatsumi K: Synergistic effects of ACE Insertion/deletion and GNB3 C825T polymorphisms on the efficacy of PDE-5 inhibitor in patients with pulmonary hypertension. Respiration 91: 132-140, 2016.

82. Sperling H, Eisenhardt A, Virchow S, Hauck E, Lenk S, Porst H, Stief C, Wetterauer U, Rubben H, Muller N and Siffert W: Sildenafil response is influenced by the $G$ protein beta 3 subunit GNB3 C825T polymorphism: A pilot study. J Urol 169: 1048-1051, 2003

83. Bell CG, Xia Y, Yuan W, Gao F, Ward K, Roos L, Mangino M, Hysi PG, Bell J, Wang J and Spector TD: Novel regional age-associated DNA methylation changes within human common disease-associated loci. Genome Biol 17: 193, 2016.

84. Murray R, Bryant J, Titcombe P, Barton SJ, Inskip H, Harvey NC, Cooper C, Lillycrop K, Hanson M and Godfrey KM: DNA methylation at birth within the promoter of ANRIL predicts markers of cardiovascular risk at 9 years. Clin Epigenetics 8: 90 , 2016.

85. Pal S and Tyler JK: Epigenetics and aging. Sci Adv 2: e1600584, 2016.
86. Wu X, Cao N, Fenech M and Wang X: Role of sirtuins in maintenance of genomic stability: Relevance to cancer and healthy aging. DNA Cell Biol 35: 542-575, 2016.

87. Perng W, Villamor E, Shroff MR, Nettleton JA, Pilsner JR, Liu Y and Diez-Roux AV: Dietary intake, plasma homocysteine and repetitive element DNA methylation in the Multi-Ethnic Study of Atherosclerosis (MESA). Nutr Metab Cardiovasc Dis 24: 614-622, 2014.

88. Needham BL, Smith JA, Zhao W, Wang X, Mukherjee B, Kardia SL, Shively CA, Seeman TE, Liu Y and Diez Roux AV: Life course socioeconomic status and DNA methylation in genes related to stress reactivity and inflammation: The multi-ethnic study of atherosclerosis. Epigenetics 10: 958-969, 2015.

89. Guerrero-Preston R, Goldman LR, Brebi-Mieville P, Ili-Gangas C, Lebron C, Witter FR, Apelberg BJ, Hernández-Roystacher M, Jaffe A, Halden RU and Sidransky D: Global DNA hypomethylation is associated with in utero exposure to cotinine and perfluorinated alkyl compounds. Epigenetics 5: 539-546, 2010.

90. Chater-Diehl EJ, Laufer BI, Castellani CA, Alberry BL and Singh SM: Alteration of gene expression, DNA methylation and histone methylation in free radical scavenging networks in adult mouse hippocampus following fetal alcohol exposure. PLoS One 11: e0154836, 2016.

91. Garcia-Lacarte M, Milagro FI, Zulet MA, Martinez JA and Mansego ML: LINE-1 methylation levels, a biomarker of weight loss in obese subjects, are influenced by dietary antioxidant capacity. Redox Rep 21: 67-74, 2016.

92. Marques-Rocha JL, Milagro FI, Mansego ML, Mourão DM, Martínez JA and Bressan J: LINE-1 methylation is positively associated with healthier lifestyle but inversely related to body fat mass in healthy young individuals. Epigenetics 11: 49-60, 2016.

93. Carraro JC, Mansego ML, Milagro FI, Chaves LO, Vidigal FC, Bressan J and Martínez JA: LINE-1 and inflammatory gene methylation levels are early biomarkers of metabolic changes: Association with adiposity. Biomarkers 21: 625-632, 2016.

94. Nicoletti CF, Nonino CB, de Oliveira BA, Pinhel MA, Mansego ML, Milagro FI, Zulet MA and Martinez JA: DNA methylation and hydroxymethylation levels in relation to two weight loss strategies: Energy-restricted diet or bariatric surgery. Obes Surg 26: 603-611, 2016.

95. Weiner R, El-Sayes I, Manger T, Weiner S, Lippert H and Stroh C; Obesity Surgery Working Group, Competence Network Obesity: Antidiabetic efficacy of obesity surgery in Germany: A quality assurance nationwide survey. Surg Obes Relat Dis 10: 322-327, 2014.

96. Stroh C, Weiner R, Wolff S, Knoll C and Manger T; Obesity Surgery Working Group; Competence Network Obesity: Influences of gender on complication rate and outcome after Roux-en-Y gastric bypass: Data analysis of more than 10,000 operations from the german bariatric surgery registry. Obes Surg 24: 1625-1633, 2014 International (CC BY-NC-ND 4.0) License. 